\title{
RISING EVIDENCE ON MEDITATION
}

\author{
Mário Henrique Elesbão de Borba ${ }^{a}$
}

\begin{abstract}
A Meta-analysis conducted by Madhay Goyal, M.D., M.P.H. was published on line January $6^{\text {th }}$ in JAMA Internal Medicine. Dr. Goyal is assistant professor at the Johns Hopkins University School of Medicine in the Division of General Internal Medicine. One of the objectives was to evaluate if the benefits of meditation could be similar to what we observe with placebo effect. Despite of limitations the trials showed better effect with meditation, what is most relevant in a time where we've seen many trials applying the concept of non inferiority. It's a very important research center publishing relevant information in a very important Journal. This demonstrates the increase interest for this issue. Many conclusions came with this article, some sentences from the authors like: "... no harm came from meditation.", also "Meditation programs appear to have an effect above and beyond the placebo."; these two sentences can be observed in the most researches evolving this issue, that's why we must encourage this practice, there's enough evidence for we suggest for ours patients and for ourselves to make that.
\end{abstract}

Key words: Meditation. Mindfulness. Medical mainstream. Placebo effect.

This must be a very exciting year, we must have a lot of progress in this area, since in the first week we were presented to a systematic review that can increase our Medical Knowledge and improve the comprehension about our patients and about ourselves. The Meta-analysis ${ }^{(1)}$ was conducted by Madhay Goyal, M.D., M.P.H. One of the objectives was to evaluate if the benefits of meditation could be similar to what we observe with placebo effect. Despite of limitations the trials showed better effect with meditation, what is most relevant in a time where we've seen many trials applying the concept of non inferiority. Dr. Goyal is assistant professor at the Johns Hopkins University School of Medicine in the Division of General Internal Medicine. The paper was published on line January $6^{\text {th }}$ in JAMA Internal Medicine. ${ }^{(2)}$ So, it's a very important research center publishing relevant information in a very important Journal. This demonstrates the increase interest for this issue.

That's an evidence that we're living a time of changes, but that's not occurring because of something new, but we're reviewing ancient concepts. Many conclusions came with this article, but l'd like to salient some sentences from the authors, starting with: “... no harm came from

a. MD, Cardiologist, Director of Cardio Clinica do Vale - Lajeado - RS; Scientific Director of GEMCA - Study Group on Cardiovascular Medicine and Spirituality of Brazilian Society of Cardiology (SBC). E-mail: mborba@cardiol.br 
meditation." (2), also "Meditation programs appear to have an effect above and beyond the placebo." (2); these two sentences can be observed in the most researches evolving this issue, that's why we must encourage this practice, there's enough evidence for we suggest for ours patients and for ourselves to make that.

That's curious because despite this many evidences showed in these articles, it's seems to be not good enough for this next step, it's still absent of our medical mainstream. Also we see that everyone who studies, not just read about, but studies this subject became convinced that meditation is a powerful way to improve health, facilitating the process of healing or even preventing diseases, but even so there's a lot of misunderstanding and confusion about what is meditation and how does it work.

The Medicine still is trying to define different kinds of Meditation and if it's a passive or active situation, the investigators empathize that, in their words: "A lot of people have this idea that meditation means sitting down and doing nothing. But that's not true. Meditation is an active training of the mind to increase awareness, and different meditation programs approach this in different ways." (2) Also there are some questions still not answered, if the person (patient or not) must be religious or not.

The authors point that this practice is connected with Eastern traditions especially with Religious traditions as Buddhism, but all Religions motivate this practice. Islam, Hinduism and even in Christianism, all of them, there is an encouragement for getting silent, calm and be full of peace, usually it has been called pray, but the concept of pray maybe also needs a systematic review, who oriented Christianism recommended: "... enter into thy closet, shut thy door and pray in secret... for your Father knows what things you have need of." (3)

Furthermore it's not a prerogative of religious community, Einstein used to say: "I think ninety nine times and nothing happens... stop thinking and dive into a deep silence and the truth reveals itself." (4) Philosophers also are used to point this direction, as Plotinus: "Retract yourself and observe". In the Delphos's temple is written: "know-you". This kind of recommendation, the search for being silent, to valorize the inner world is not a privilege of Jesus,
Buda or Einstein, but is a council of everyone that escape from trap of the world's rush, and all of them give us many appointments that this is the way for happiness and peace, but it's not enough to know the path, we must walk the path.

The authors detach the mindfulness Meditation as the most effective, or at least the most researched. Maybe it seems to have more effectiveness, maybe the cost/benefit of this practice is more likely in our society where the most of people is stuck in the mud of our status quo. There are a lot of maybes, however when we go deep in the study we see that those that are walking this path prefer to empty the mind, to turn the mind receptive. This capacity to be receptive allow us to listen the Father or to enlighten our Being or to connect with Cosmic Consciousness, we can pick the term that we prefer, all of them means the same.

The most clinical trials involved mental health as symptoms of anxiety, depression and pain, but here the investigators also focused on some physical health. I have many difficulties to understand that division, but that is another question for other moment. As a cardiologist, I must say that the practice of meditation may benefit also heart disease, including hypertension and heart failure. Maybe because when we go inside ourselves we give the first step for true knowledge of ourselves and after knowing we can control, it's impossible to control what we don't know. And, in the moment that we realize how we behave towards different situations, after that we can anticipate our response and control how much adrenaline we need to confront with that moment and decide if we need outbrave or just let that situation go.

Then we remember what the most important people taught $u$. Buda gave us the Impermanence Concept ${ }^{(5)}$ and Jesus recommends us: "take no trouble thought for tomorrow" (6) and also "let not your heart be troubled".(7) Last year a study from University of Buffalo conducted by psychologist Michael Poulin found: "it actually is better and healthier to give than to receive." (8) It's also an old sentence. Maybe it's time to have a deep review for this ancient concepts, we talk about anxiety, stress, pain... Our society seems to have a lot of pains: physical, mental and soul's pains. Perhaps we should reconsider some old teachings for those pains as Paul in the Letter for Philippians that 
was wroten while he was in prison, he recommended for the past (where are the causes of guiltiness or faults) that we should forget about it, for the present (where are our sadness) that we should see just the blesses and for the future (where are our anxieties) that we should trust in the Christ, and again we can change this word for God, Light, Love or Universe.

\section{References}

1. Goyal M, Singh S, Sibinga EM, Gould NF, RowlandSeymour A, Sharma R et al. Meditation Programs for Psychological Stress and Well-being: A Systematic Review and Meta-analysis. JAMA Intern Med. 2014. Ahead of print.
2. Mathew 6, 6-9, The New Testament, King James Version.

3. Einstein A. The World as I See It. 1949.

4. Rinpoche S. The Tibetan Book of Living and Dying. [Pimble, Australia]: Perfect Bound; 1992.

5. Mathew 6, 34, The New Testament, King James Version.

6. John 14, 1, The New Testament, King James Version.

7. Donovan P. Study finds it actually is better (and healthier) to give than to receive. 2013. Avaliable from: http://www.buffalo.edu/news/ releases/2O13/O2/OO3.html 